\title{
NILAI - NILAI QURANI DAN SUNNAH NABI DALAM PRAKTIK JUAL BELI PADA PASAR TERAPUNG DI KALIMANTAN SELATAN
}

\section{Quranic and Sunnah Values of Prophets in Buy and Sell Practice on Floating Market in South Kalimantan}

\author{
${ }^{*}$ Ariyadi \\ Al Ahwal Al Syakhshiyah Study Program, Universitas Muhammadiyah Palangkaraya, RTA Milono St. Km.1,5 \\ Palangka Raya, Indonesia \\ *e-mail : ariyadialbanjari@gmail.com
}

\begin{abstract}
ABSTRAK
Penelitian ini berangkat dari aktifitas yang sering dilakukan oleh masyarakat banjar yang selalu diidentikan dengan Islam. Secara sosiologis, keidentikan masyarakat banjar dengan islam merujukkan kepada identitas sosial yang merefleksikan suatu dasar ikatan sosial yang sama. Secara historis, Islam dijadikan sebagai sebuah poros sistem perdagangan oleh masyarakat banjar. Ini berarti bahwa perilaku orang banjar dapat dicarikan sumbernya pada referensi islam, termasuk di dalamnya adalah perilaku orang banjar dalam bertransaksi jual beli baik dalam kajian ayat-ayat maupun hadits. Penelitian ini bertujuan untuk mengetahui bagaimana cara transaksi jual beli dipasar terapung di Kalimantan Selatan, bagaimana akad transaksi jual beli di pasar terapung di Kalimantan Selatan serta apa dalil yang mendasari masyarakat di Kalimantan Selatan dalam bertansaksi jual beli dipasar terapung. Dengan demikian, setidaknya yang selama ini menjadi titik masalah dapat terungkap dan dapat menjadi informasi ilmiah yang mencerahkan. Penelitian ini merupakan penelitian lapangan (field research), penelitian ini bersifat deskriptif, dimana data-data yang dikumpulkan dianalisis secara kualitatif. Untuk memperoleh data yang diperlukan. Penulis melakuan observasi, dokumentasi dan wawancara secara langsung kepada sebagian pedagang Pasar Terapung di Kalimantan Selatan. Melalui teknik analisis kualitatif dari penelitian ini menghasilkan temuan-temuan: Pertama, cara transaksi jual beli dipasar perapung di Kalimantan Selatan (1) Barter,(Barang dengan barang yang setara) (2) Transaksi jual beli barang dengan alat tukar (uang). Kedua, akad yang digunakan di perbohkan selagi tidak bertentangan prinsip-prinsip syariat Islam. Ketiga, Adapun nilai-nilai Qur'ani yang menjadi rujukan masyarakat banjar adalah surat an-Nisa' 29, surat al-Jum'ah 11, surat an-Nur 37, surat al-Baqarah 282, surat at-Taubah 24, dan surat Hud 84-85. Dan sunnah nabi tentang suka sama suka, larangan mulamasah dan mulamazah. Dan masih banyak lagi sunnah nabi yang berhubungan dengan transaksi.
\end{abstract}

Kata kunci: Nilai - nilai Qurani, Nilai - nilai Sunnah, Praktek Jual Beli, Pasar Terapung

\begin{abstract}
This research departs from the activities that are often done by the Banjar community which is always identified with Islam. Sociologically, the identity of the Banjar community with Islam refers to a social identity that reflects a common social bonding foundation. Historically, Islam was used as a pivot of trading system by Banjar society. This means that the behavior of Banjar people can be searched the source on Islamic references, including in it is the behavior of Banjar people in trading and selling both in the study of verses and hadith. This study aims to find out how to buy and sell floating market in South Kalimantan, how to buy and sell transaction agreement in floating market in South Kalimantan and what is the underlying proposition of people in South Kalimantan in trading and selling floating market. Thus, at least that has been the point of trouble can be revealed and can be scientific information that brightens. This research is a field research (field research), this research is descriptive, where the data collected were analyzed qualitatively. To obtain the required data. The author conducted observations, documentation, and interviews directly with some traders Floating Market in South Kalimantan. Through qualitative analysis technique from this research resulted from the findings: First, how to buy and sell floating market in South Kalimantan (1) Barter, (Goods with equivalent goods) (2) Sale and purchase transaction of goods by means of exchange (money). Second, the contracts used in the bullet while not contradicting the principles of Islamic law. Thirdly, the Quranic values referenced by the Banjar community are an-Nisa '29, al-Jum'ah 11, an-Nur 37, alBaqarah 282, at-Taubah 24, and letters Hud 84-85. And the Sunnah of the Prophet about likes, prohibitions of mulamasah and mulamazah. And many more sunnah of the prophet associated with the transaction
\end{abstract}

Keywords: Quran Values, Sunnah Values, Buy and Sell Practice, Floating Market 


\section{PENDAHULUAN}

Penelitian ini berangkat dari aktifitas yang sering dilakukan oleh masyarakat banjar yang selalu diidentikan dengan Islam. Secara sosiologis, keidentikan masyarakat banjar dengan islam merujukkan kepada identitas sosial yang merefleksikan suatu dasar ikatan sosial yang sama. Secara historis, Islam dijadikan sebagai sebuah poros sistem perdagangan oleh masyarakat banjar. Pada umumnya manusia mempunyai banyak kebutuhan yang harus dipenuhi untuk kelangsungan hidupnya. Berbicara mengenai kebutuhan, Kebutuhan adalah syarat hidup dasar manusia. Orang membutuhkan udara, makan, tempat tinggal, pakaian untuk bertahan hidup. Kebutuhan-kebutuhan ini menjadi keinginan ketika diarahkan ke objek tertentu yang dapat memuaskan kebutuhan tersebut.

Banyak kegiatan yang dapat dilakukan manusia untuk memenuhi kebutuhannya, salah satunya adalah dengan melakukan jual beli. Jual beli merupakan kegiatan tukar menukar barang atau sesuatu yang memberi manfaat bagi pelakunya. Dalam ajaran Islam jual beli merupakan bagian dari muamalah yang diatur sedemikian rupa, sehingga tidak bertentangan dengan Al-Qur'an dan sunah Nabi Muhammad SAW. Sebagaimana dalam firman Allah Q.S. alBaqarah/2: 275.

"Orang-orang yang makan (mengambil) riba tidak dapat berdiri melainkan seperti berdirinya orang yang kemasukan Syaitan lantaran (tekanan) penyakit gila. Keadaan mereka yang demikian itu, adalah disebabkan mereka berkata (berpendapat), Sesungguhnya jual beli itu sama dengan riba, Padahal Allah telah menghalalkan jual beli dan mengharamkan riba. Orang-orang yang telah sampai kepadanya larangan dari Tuhannya, lalu terus berhenti (dari mengambil riba), Maka baginya apa yang telah diambilnya dahulu (sebelum datang larangan); dan urusannya (terserah) kepada Allah. orang yang kembali (mengambil riba), Maka orang itu adalah penghuni-penghuni neraka; mereka kekal di dalamnya".

Dalam ayat ini Allah SWT menceritakan masalah orang-orang yang memakan riba dari harta kekayaan orang lain dengan cara yang tidak dibenarkan serta berbagai macam syubhat. Lalu Allah SWT mengibaratkan tentang keadaan mereka pada hari kiamat. Maksud dari ayat ini adalah Allah SWT menghalalkan jual beli dan mengharamkan riba. Jadi transaksi jual beli itu dihalakan oleh Allah SWT asalkan tidak mengandung unsur riba di dalamnya. Dalam memenuhi kebutuhan hidup manusia mulai melakukan pertukaran barang-barang antara satu dan lainya yang kebetulan saling membutuhkan (double coincidence), sistem ini dikenal dengan perekonomian barter. Salah satu bentuk pasar adalah pasar terapung, yang berada di atas perairan dan menggunakan jukung sebagai transportasi perdagangan. Pasar Terapung. DiIndonesia Pasar Terapung ini hanya ada di Provinsi Kalimantan Selatan. Ada tiga lokasi Pasar Terapung di Kalimantan Selatan, yaitu di daerah Kuin Banjarmasin, di Siring kota Banjarmasin, dan di Desa Lok Baintan, Kecamatan Sungai Tabuk, Kabupaten Banjar.

Jual beli secara bahasa (Lughatan) berasal dari bahasa Arab al-bai',at- tijarah al-mubadalah artinya "mengambil", atau menukarkan sesuatu dengan sesuatu. Ahbah az-Zuhaili meyebutkan: "Jual beli adalah proses tukar-menukar barang dengan barang". Menurut Taqiyuddin: "Memberikan sesuatu dengan imbalan sesuatu". Muhammad Ismail al-Kahlany "Pemilikan suatu harta dengan harta yang lain". Dan juga Jual beli 
adalah terjemahan dari kata Al-Bai'u. Al-Bai'u secara etimologi adalah mengambil dan memberikan sesuatu. la diambil dari kata ba'a, di mana seseorang menjulurkan tangannya saat melakukan transaksi atau ketika mengambil yang ditransaksikan, baik uang atau barang. Secara istilah, para ulama berbeda pendapat dalam mendefinsikannya, antara satu dan lain: Menurut Sayyid sabiq, jual beli adalah: "Saling menukar sesuatu harta dengan suka sama suka atau memindahkan hak milik (kepada orang lain) dengan sesuatu pengganti dengan cara yang dibenarkan oleh syara".

Imam Taqiyuddin jual beli adalah: Pertukaran harta dengan harta secara timbal balik untuk dipergunakan atau dimanfaatkan dengan ijab kabul menurut cara yang telah ditentukan".

Serta Hasbi Ash-Shiddiqie jual beli adalah: Aqad yang tegak atas dasar penukaran harta dengan harta, maka jadilah penukaran hak milik secara tetap".

Adapun Dasar Pembahasan mengenai Hukum Jual Beli meliputi:

1. Dalil yang bersumber dari Alquran diantaranya:

a. Surah Al-Baqarah ayat 275.

b. Surah An-Nisa ayat 29.

c. Surah Al-Jumu'ah ayat 9 .

2. Dalil yang bersumber dari Hadis diantaranya:

a. "Dari Rifa'ah Ibnu Rafi' r.a. bahwa Rasulullah saw. pernah ditanya: Pekerjaan apakah yang paling baik?. Beliau bersabda: "Pekerjaan seseorang dengan tangannya dan setiap jual-beli yang mabrur (bersih)".(H.R. Al-Bazzar dan disahkan Hakim).

b. Sabda Rasulullah saw, 'Dari Abdullah bin Harits katanya, aku mendengar Hakim bin
Hazam Ra bahwa Nabi saw bersabda. "Dua orang yang melaksanakan jual beli boleh melakukan khiyar selama mereka belum berpisah Jika keduanaya benar dan jelas, keduanya diberkati dalam jual beli mereka. Jika mereka menyembunyikan dan berdusta, Tuhan akan memusnahkan keberkatan jual beli merek"a (H.R.BukhariMuslim)

3. Ijma'

Umat Islam telah sepakat (ijma') atas kebolehan jual beli dan pelaksanaannya sudah berlaku (dibenarkan) sejak zaman Rasulullah saw hingga hari ini.

Dengan demikian jual beli hukumnya boleh selama tidak dilaksanakan dengan cara melanggar aturan agama, sebagaimana yang terdapat dalam kaidah ushul fiqih yaitu:

"Asal akad dan muamalah adalah sah, sehingga ada dalil yang membatalkan dan mengharamkannya."

Berdasarkan keterangan yang berasal dari beberapa dalil di atas, maka jelaslah bahwa jual beli itu hukumnya dibolehkan menurut Alquran dan Hadis serta ljma' umat Islam selama jual beli itu dilaksanakan sesuai dengan rukun dan syaratnya tanpa ada unsur paksaan, kecurangan dan tipuan, didalamnya dan hendaknya dilakukakan dengan kejujuran dan keikhlasan sehingga tercipta rasa suka sama suka di antara kedua belah pihak.

Transaksi jual beli ada beberapa unsur yang harus dipenuhi, sehingga transaksi jual beli dapat berjalan sesuai dengan ketentuan syara' maka dikenal istilah rukun dan syarat jual beli.

Rukun jual beli tersebut adalah sebagai berikut:

1. Akad (ijab kabul) 
2. Orang yang berakad

3. Barang yang menjadi objek transaksi.

Syarat jual beli tersebut adalah sebagai berikut:

1. Suci bukan benda benda najis seperti anjing dan yang lainnya.

2. Memberi manfaat menurut syara'

3. Jangan digantungkan, seperti jika ayahku pergi, ku jual motor ini kepadamu.

4. Tidak dibatasi waktunya.

5. Dapat diserahkan dengan cepat maupun lambat.

6. Milik sendiri.

7. Diketahui, baik banyaknya, takarannya, atau ukuran-ukuran yang lainnya, maka tidaklah sah jual beli yang menimbulkan keraguan salah satu pihak

Berdasarkan ketentuan Islam, setiap perbuatan haruslah memenuhi kedua unsur tersebut, yaitu rukun dan syarat-syaratnya.

\section{METODOLOGI}

Penelitian ini pasar terapung yang dimaksud ialah ketiga pasar terapung yang ada di Kalimantan Selatan yang akan menjadi objek penelitian. Di Pasar Terapung ini menjual berbagai jenis barang seperti, bibit-bibit tanaman, hasil produksi pertanian/perkebunan, buah-buahan, sembako, wadai (kue) dll. Pasar Terapung ini berlangsung tidak terlalu lama, paling lama sekitar tiga hingga empat jam, yaitu sekitar pukul 06.00 wita hingga 09.00 Wita.

Transaksi jual beli di Pasar Terapung ini kebanyakan dilakukan oleh sesama pedangan dibandingkan masyarakat yang bukan pedagang dan pedagangnya di dominasi perempuan. Bahkan sebagian pedagang di Pasar Terapung ini masih menggunakan praktik barter. Dalam jual beli barter, sesama pedagang biasanya saling menukarkan barangnya sesuai dengan yang dibutuhkannya. Walaupun di Pasar Terapung ini sudah banyak pedagang yang menggunakan uang pada transaksi jual beli. Dari hasil obserasi diketahui praktik barter ini sudah mulai ditinggalkan masyarakat dikarenakan kebanyakan pedagang pada saat ini berinteraksi menggunakan uang yang lebih mudah digunakan. Namun berbeda halnya dengan yang ada di Pasar Terapung di Kalimantan Selatan, masih ada sebagian pedagang yang melakukan praktik barter antar sesama pedagang. Ini berarti bahwa perilaku orang banjar dapat dicarikan sumbernya pada referensi islam, termasuk di dalamnya adalah perilaku orang banjar dalam bertransaksi jual beli baik dalam kajian ayat-ayat maupun hadits.

Pasar Terapung Lok Baintan adalah salah satu pasar tradisional yang berada di aliran sungai Martapura tepatnya di Desa Lok Baintan, Kecamatan Sungai Tabuk, Kabupaten Banjar. Kegiatan di Pasar Terapung ini berlangsung setiap hari dari pukul 06:00 sampai 09:00. Pedagang disini biasanya menggunakan perahu untuk berjualan, Selain transaksi dilakukan di atas jukung (perahu), pedagang dan pembelinya juga tidak terpaku di suatu tempat, tetapi terus bergerak mengikuti arus sungai yang menjual beragam dagangan, seperti hasil produksi pertanian/perkebunan dan pedagangnyapun didominasi perempun.

Untuk menuju Pasar Terapung Lok Baintan bisa ditempuh dengan dua alternatif. Alternatif pertama, menyusuri sungai martapura dengan menggunakan Kelotok (kapal kayu/prahu motor), perjalanan dari Pusat Kota Banjarmasin dapat 
ditempuh sekitar 60 menit. Alternatif kedua, dengan menggunakan kendaraan darat seperti mobil.

Pasar terapung ini Sama seperti pasar terapung lokba intan, namun lokasi nya yang berbeda yakni berada di atas sungai Barito di muara sungai kuin. Alamat lengkap pasar terapung muara kuin yaitu di Jl. Kuin Utara, Kel. Kuin Selatan, Kec. Banjarmasin Barat, Kota Banjarmasin, Kalimantan Selatan. Untuk menuju ke Pasar Terapung Muara Kuin kita bisa langsung ke jalan Kuin Utara, lalu naik perahu kelotok atau perahu motor yang biasanya banyak terdapat di dermaga-dermaga di sepanjang sungai kuin. Salah satunya bisa melalui dermaga yang berada di dekat Masjid bersejarah Sulltan Suriansyah. Sama dengan pasar terapung lokba intan, mulai operasi pasar terapung ini setelah sholat subuh, sekitar jam 05.00 Pagi sampai matahari terbit sekitar jam 08.00 .

Beda dengan pasar terapung sebelumnya, pasar terapung di siring sungai martapura ini adalah program giat pasar Terapung oleh pemerintah kota Banjarmasin dalam rangka melestarikan Pasar Terapung.

Lokasi pasar terapung ini yaitu di Siring Sungai Martapura di Jl. Kapten Piere Tandean Kota Banjarmasin, Kalimantan Selatan. Namun tidak seperti pasar terapung yang lainnya yang buka setiap hari, pasar terapung di sini bukanya hanya setiap hari Minggu pagi dari Jam 07.00 sampai 12.00 WITA. Dengan pelaksanaan Pasar Terapung di Siring sungai Martapura yang terletak di pusat kota diharapkan dapat lebih mendekatkan pasar terapung dengan masyarakat. Selain itu mungkin karena di sekitar pasar terapung ini juga terdapat objek wisata yang menarik lainnya, seperti Menara Pandang, Siring sungai martapura, dan patung bekantan menjadikan pasar ini semakin ramai.

Di Pasar Terapung ini para pedagang merapat di area pinggiran siring, dan pembeli di atas titian yang mengapung dengan alas bambu. Pasar terapung siring sungai martapura ini paling ramai di kunjungi di bandingkan Pasar Terapung Kuin dan Pasar Terapung Lok Baintan, mungkin karena mudahnya akses ke sini dan waktu yang lumayan panjang beroperasinya pasar tradisional ini, menjadikan Pasar Terapung Siring Sungai Martapura sebagai hiburan favorit masyarakat Banjarmasin untuk mengisi waktu liburan bersama keluarga atau teman-teman.

\section{HASIL DAN PEMBAHASAN}

Untuk mengetehui nilai-nilai Qurani dan Sunnah Nabi pada pasar terapung di Kalimantan Selatan, seiring peneliti melakukan penelitian terhadap enam pedagang yang pada masing-masing pasar terapung hanya dua pedagang di tiap lokasi, dapat diketahui dari data yang peneliti kumpulkan dengan teknik wawancara dan observasi dengan uraian sebagai berikut:

1. SS ialah salah satu pedagang yang ada di pasar Terapung Lok Baintan, dia sudah lama berjualan dipasar tersebut sekitar 14 tahun, biasanya dia pergi berjualan sekitar jam 05:5006:00 pagi sampai jam 09:00 pagi. Dia menjual sayur-sayuran dan buah-buahan, Dari hasil wawancara yang saya lakukan dengan SS, SS mengatakan bahwa sebelum berangkat terlebih dulu dia melaksanakan sholat subuh, baru setelah itu dia berangkat ke Pasar Terapung Lok Baintan untuk menjajakan dagangannya, dalam menjajakan dagangannya dia juga mengatakan dalam 
berdagang dia masih menggunakan praktik jual beli barter selain uang dengan barang.

2. SS melakukan praktik barter dikarenakan pada saat itu dia bertemu dengan pedagang lain yang sama-sama membutuhkan barang yang mereka inginkannya, pedagang yang menjadi rekan barternya, biasanya menawarkan terlebih dahulu untuk menukarkan ikan dengan sayur milik SS dengan nilai harga yang sama, karena menurut SS bertransaksi seperti itu mudah tanpa harus mengeluarkan uang dan harganya pun senilai dengan barang yang ditukarkannya, Saya pun langsung menyetujuinya katanya dengan alasan melakukan barter karena atas dasar suka sama suka.

3. SM merupakan pedagang buah dipasar Terapung Lok Baintan, dia sudah lama berjualan dipasar terapung Lok Baintan ini, kurang lebih 12 tahunan. Setiap hari, sekitar pukul 06:00 pagi sampai 09:15 wita. SM membawa buah-buahan untuk dijualnya dipasar Terapung Lok baintan tersebut. SM mendapatkan buah-buahannya tersebut dari hasil kebun sendiri, tapi terkadang SM juga membeli buah-buahan dari orang lain .

SM mengatakan sebelum melakukan praktik perdagangan dipasar terapung ia terlebih dulu melaksanakan kewajiban dia selaku muslim (sholat subuh) dan ibu rumah tangga menyiapkan segala keperluan untuk keluarganya baru dia berangkat sesampainya di Pasar Terapung dia biasanya bertrasansi barter dikarenakan pada saat itu dia bertemu dengan pedagang lain yang sama-sama membutuhkan barang yang mereka inginkannya, pedagang yang menjadi rekan barternya, biasanya menawarkan untuk menukarkan ikan, beras bahkan sayur dengan nilai harga yang sama, karena menurut SM bertransaksi seperti ini sudah digunakan sejak lama oleh pedagang-pedagang, dulu orang tidak menggunakan uang dalam transaksi jual beli, melainkan dengan menukarkan barang dengan barang untuk keperluan sehari-hari. SM menyebutkan praktik barter ini sudah ada sejak lama, sehingga sulit untuk dihilangkan, walaupun sekarang hampir tidak ada lagi yang menggunakan praktik barter tersebut karena atas dasar suka sama suka.

4. J seorang pedagang yang ada dipasar Terapung Muara Kuin, biasanya dia menjual buah-buahan seperti, buah pisang, jambu, jeruk, rambutan, mangga dan semangka. Barang yang dia jualpun merupakan hasil kebun sendiri dan sebagian ada juga yang dibelinya dari orang lain. setiap hari pukul 06:00 dia sudah berangkat kepasar Terapung untuk berjualan dan pulang sekitar pukul 09:00 pagi. $J$ sudah sangat lama berjualan dipasar terapung ini, sejak umur 21 tahun.

5. J biasanya bertransaksi barter dikarenakan pada saat itu dia bertemu dengan pedagang lain yang sama-sama membutuhkan barang yang mereka inginkannya, pedagang yang menjadi langganan barter, biasanya menawarkan untuk menukarkan ikan, dan beras atau bahan keperluan rumah tangga dengan nilai harga yang sama, karena menurut $J$ bertransaksi seperti ini sudah digunakan sejak lama, dulu orang tidak menggunakan uang dalam transaksi jual beli, melainkan dengan menukarkan barang dengan barang untuk keperluan sehari-hari. praktik barter 
tersebut karena atas dasar suka sama suka dan tidak unsur tipi menipu diantara mereka.

6. $\mathrm{R}$ adalah penjual ikan yang ada di pasar Terapung Muara Kuin, sewaktu kecil R sudah mulai ikut berjualan dipasar terapung ini bersama orang tuanya, sampai pada akhirnya $\mathrm{R}$ meneruskan pekerjaan orang tuanya sebagai pedagang di pasar terapung. Sama halnya seperti pedagang lainnya Rahmadi berangkat berdagang dari jam 06:00 pagi dan pulang sekitar jam 09:10 pagi, $R$ tidak biasa setiap hari berjualan ikan dipasar terapung, $\mathrm{R}$ berangkat ke Pasar Terapung dia biasanya bertransaksi barter dikarenakan pada saat itu dia bertemu dengan pedagang dan penjual dia meperioritaskan adanya transaksi dengan uang tpi jika ada pedagang lain yang sama-sama membutuhkan ikan yang mereka inginkan, biasanya menawarkan untuk menukarkan sayur, buah-buahan, dan beras atau bahan keperluan rumah tangga dengan nilai harga yang sama, karena menurut $R$ bertransaksi seperti ini sudah ada sejak lama sejak dia masih kecil dan masih ikut orang tuanya bekerja, yang terpenting atas dasar suka sama suka dan tidak unsur tipi menipu diantara mereka $\mathrm{NH}$ seorang ibu pedagang yang ada dipasar Terapung siring, biasanya dia menjual buah-buahan seperti, buah pisang, jambu, jeruk, rambutan, mangga dan semangka. Barang yang dia jual pun merupakan hasil kebun sendiri dan sebagian ada juga yang dibelinya dari orang lain. Dia berjualan hanya pada hari minggu pukul 06:30 dia sudah berangkat.

7. $\mathrm{NH}$ biasanya bertransaksi barang dengan uang karena yang membeli dengan pedagang ialah masyarakat yang sambil berlibur di pinggir siring kota Banjarmasin

8. $\mathrm{H}$ seorang ibu pedagang yang ada dipasar Terapung siring, biasanya dia menjual wadai (kue) seperti, cucur, putu mayang, buras, dll. Barang yang dia jual pun merupakan hasil kebun sendiri dan sebagian ada juga yang dibelinya dari orang lain. Dia berjualan hanya pada hari minggu pukul 06:30 dia sudah berangkat .

$\mathrm{H}$ dia mengatakan kami jarang menggunakan barter dalam bertransaksi dengan barang baik dengan sesama pedagang atau dengan masyarakat biasanya bertransaksi dengan uang sebagai alat tukar karena yang membeli masyarakat yang sedang berlibur bersama keluarga dan anak muda mudi yang singgah saat sedang berolah raga di pinggir siring kota Banjarmasin.

Untuk mengetahui nilai-nilai qurani dan sunnah nabi dalam praktik jual beli di Pasar Terapung setidaknya ada beberapa nilai yang daapat kita jadikan hikmah untuk kehidupan sehari-hari pada praktik jual beli masyarakat di pasar terapung kalimantan selatan:

1. Khiyar kondisi suka sama suka ('an taradhin) antara pembeli dengan pedagang atau pedagang dengan pedagang itu diwujudkan di tempat berlangsungnya jual beli tersebut. Dalam hal ini menurut ajaran Islam hak seseorang sangat diihormati. Kemauan adalah hak pembeli, maka ia tidak boleh dipaksa membeli sesuatu. Hal ini seperti seperti yang diungkapkan Sayyid Sabiq, mungkin terjadi salah satu pihak melakukan jual beli dengan cara tergesa-gesa. Setelah berlangsungnya nampak adanya keperluan yang menuntut 
pembatan jual beli tersebut. Bila tidak dibatalkan tentu akan merusak kerelaan dari yang bersangkutan, karena jual beli itu merugikan salah satu pihak. Dalam hal ini si pembeli dapat membatalkan transaksi jual beli selagi ia masih berada di tempat berlangsung. Ketentuan ini disebut dengan khiyar majlis. Sabda Rasulullah saw, dari Abdullah bin Harits yang diriwayatkan oleh Bukhari dan Muslim tentang kebolehan melakukan khiyar. Pembatalan jual beli juga bisa dilakukan oleh pembeli bila dia menemukan sesuatu cacat pada komoditas yang dia beli. Ini disebut dengan khiyar aib. Penemuan cacat barang tersebut ditemukan pembeli setelah transaski berlangsung. Tetapi bila cacat tersebut diketahui sebelum transakssi dan si pembeli tetap membelinya juga, maka transaksi tersebut tidak dapat dibatalkan lagi sebab si pembeli itu dipandang rela dengan barang tersebut.

2. Tidak terdapat Tadlis diantara pedagang dengan pembeli atau pedangan dengan pedagang. Transaksi yang mengandung suatu hal yang tidak diketahui oleh salah satu pihak unknown to one party. Setiap transaksi dalam Islam harus didasarkan pada prinsip kerelaan antara kedua belah pihak (sama-sama ridha). Mereka harus complete information (mempunyai informasi yang sama) sehingga tidak ada pihak yang merasa ditipu atau dicurangi karena ada sesuatu yang keadaan di mana salah satu pihak tidak mengetahui informasi yang diketahui pihak lain, ini merupakan asymetric information. Unknown to one party dalam bahasa fikih disebut tadlis (penipuan), dan dapat terjadi dalam 4 (empat) hal, yakni dalam:

a. Kuantitas;

b. Kualitas;

c. Harga; dan

d. Waktu Penyerahan

3. Menguatkan toleransi dan persaudaraan

Pedagang dan penjual atau pedagang dengan pedagang tidak hanya mendapatkan untung tapi juga ada rasa tolong menolong. Maka muncul rasa toleransi dalam penerimaan barter (memberikan kelapangan kepada orang yang membutuhkan), tolong menolong dalam kebaikan. Selain itu tidak melakukan penipuan, seperti menonjolkan keunggulan barang tapi menyembunyikan cacatnya, melipat gandaka harga terhadap orang yang tidak mengetahui harga pasaran.

4. Mencari nafkah untuk Keluarga

Pedangang yang menjajakan daganganya dipasar terapung mempunyai tujuan yang sama yaitu untuk memenuhi/menafkahi kehidupan keluarga sehari-hari mereka. Islam mencintai seorang muslim yang giat bekerja, mandiri, apalagi rajin memberi. Sebaliknya, Islam membenci manusia yang pemalas, suka berpangku tangan dan menjadi beban orang lain. Allah subhanahu wa ta'ala berfirman:

"Maka carilah rizki disisi Allah.." (QS. Al 'Ankabut [29]: 17)

Bekerja dalam pandangan Islam begitu tinggi derajat-nya. Hingga Allah dalam Al Qur`an menggandengkannya dengan jihad memerangi orang-orang kafir.

"dan orang-orang yang berjalan di muka bumi mencari sebagian karunia Allah; dan orang- 
orang yang lain lagi berperang di jalan Allah." (QS. Al Muzzammil [73]: 20)

Rasulullah shallallahu 'alaihi wa sallam bahkan me-nyebut aktifitas bekerja sebagai jihad di jalan Allah. Diriwayatkan, beberapa orang sahabat melihat seorang pemuda kuat yang rajin bekerja. Mereka pun berkata mengomentari pemuda tersebut, "Andai saja ini (rajin dan giat) dilakukan untuk jihad di jalan Allah." Nabi shallallahu 'alaihi wa sallam segera menyela mereka dengan sabdanya, "Janganlan kamu berkata seperti itu. Jika ia bekerja untuk menafkahi anak-anaknya yang masih kecil, maka ia berada di jalan Allah. Jika ia bekerja untuk menafkahi kedua orang-tuanya yang sudah tua, maka ia di jalan Allah.

\section{KESIMPULAN}

Dari uraian dan pembahasan tentang praktik jual beli pasar terapung di Kalimantan Selatan terhadap nilai-nilai qurani dan sunnah nabi maka dapat ditarik kesimpilan sebagai berikut:

1. Cara bertransaksi jual beli dipasar perapung di Kalimantan Selatan berdapat beberapa cara

a. Barter,(Barang dengan barang yang setara)

b. Transaksi jual beli barang dengan alat tukar (uang).

2. Akad yang digunakan di pasar terapung Kalimantan Seletan secara global masih dalam ranah kebolehan baik ditijau dari syariat dan tidak bertentangan prinsip-prinsip syariat Islam.

3. Adapun nilai-nilai Qur'ani yang menjadi rujukan masyarakat banjar adalah surat an-Nisa' 29, surat al-Jum'ah 11 , surat an-Nur 37 , surat alBaqarah 282, surat at-Taubah 24, dan surat Hud 84-85. Dan sunnah nabi tentang suka sama suka, larangan mulamasah dan mulamazah. Dan masih banyak lagi sunnah nabi yang berhubungan dengan transaksi.

\section{DAFTAR PUSTAKA}

Abu Bakar Muhammad Syathaad-Dimyathi, Sayyid. 2005. I'anahAl-Thalibin. Beirut: Daar al-Fikr.

Al-Atsqalani, Ibnu Hajar. 1997M/1418H. Bulugh al-Maram min Adillati al-Ahkam. Beirut: Daar al-Fikr.

Al-Bassam, Abdullah bin Abdurrahman. 2006. Taudhih Al Ahkam min Bulugh Al Maram diterjemahkan oleh Thahirin Saputra dkk. dengan judul Syarah Bulughul Maram. Jakarta: pustaka Azzam.

Al-Kahlany, Muhammad bin Ismail. Subulus Salam. Beirut: Dar al-Kitab al-Ilmiyah.

Ash-Shiddiqie, Hasbi. 1984. Pengantar Fiqh Muamalat. Jakarta: Bulan Bintang.

Az-Zuhaili, Wahbah. 2006. Al-FiqhualIslamiwa'adillatuhu. Damaskus: Darul Fikri.

Az-Zuhaili, Wahbah. 2011. Al-FiqhualIslamiwa'adillatuhu Abdul Hayyieal- Kattani Departemen Agama RI. 2007. Al-Qur'an dan Terjemahnya. Jakarta: Gema Insani.

Hakim, Abdul Hamid. Al-Bayan. Jakarta: Sa'adiyah Putra.

Kotler, Philip dan Kevin Lane Keller. 2009. Manajemen Pemasaran. Jakarta: Erlangga.

Nawawi, Ismail. 2012. Fikih Muamalah Klasik dan Kontemporer. Bogor: Ghalia Indonesia.

Rasjid, Sulaiman. 1992. Fiqh Islam. Bandung: Sinar Baru.

Sabiq, Sayyid. 1983. Fiqh as-Sunnah. Beirut: Dar al-Fikr.

Sabiq, Sayyid. 1997. Fiqih Sunnah diterjemahkan oleh Kamaluddin A. Marzuki dkk. dengan judul Fikih Sunnah. Bandung: Alma'arif.

Salim, Agus. 2010. Praktik Barter Antara Barang Bekas dengan Mainan di Kecamatan 
Ketapang Kabupaten Sampit. Fakultas Syariah dan Ekonomi Islam IAIN Antasari Banjarmasin: Skripsi tidak diterbitkan.

Suhendi, Hendi. 2007. Fiqh Muamalah. Jakarta: PT Raja Grafindo Persada.

Taqiyuddin Abi Bakar bin Muhammad al Husaini, Imam. Kifayatul Akhyar. Beirut: Dar al-Kitab al-IImiyah. 